\title{
Swimming ontogeny of larvae of four temperate marine fishes
}

\author{
Domine L. Clark, Jeffrey M. Leis*, Amanda C. Hay, Thomas Trnski \\ Ichthyology, Division of Aquatic Science, Australian Museum, 6 College Street, Sydney, New South Wales 2010, Australia
}

\begin{abstract}
Prerequisites for understanding dispersal in pelagic larvae of demersal fishes are data on when swimming abilities of larvae are sufficiently developed to be able to alter passive dispersal trajectories. In laboratory swimming chambers, the development of critical speed and endurance swimming was measured in reared larvae of 4 species of warm-temperate marine and estuarine fishes that spawn pelagic eggs (Sciaenidae, Argyrosomus japonicus; Sparidae, Pagrus auratus, Acanthopagrus australis; Percichthyidae, Macquaria novemaculeata). Size was a better predictor of swimming ability than age. Increase in critical speed with growth was best portrayed by linear or 'flat' curvilinear relationships. Increase in endurance was best portrayed by strongly concave curvilinear relationships. The percichthyid larvae had the highest critical speed initially, but speed increased slowly with growth. The 2 sparids had the greatest increase in speed with growth, and the sciaenid the least. The greatest increase in endurance with growth was found in $P$. auratus, but performance of $M$. novemaculeata was only slightly less. The slowest increase in endurance with growth was found in A. japonicus, but, by settlement, its performance was similar to the other species. Until notochord flexion was complete, both speed and endurance were limited. Thereafter, swimming performance improved markedly at a species-specific rate. At settlement, larvae of these species could swim more than $10 \mathrm{~km}$ and at speeds of 15 to $20 \mathrm{~cm} \mathrm{~s}^{-1}$ (=12 to $\left.20 \mathrm{BL} \mathrm{s}^{-1}\right)$, which exceeded the average currents in their coastal environment. Following notochord flexion, all larvae swimming at critical speed were in an inertial environment, and this corresponded to when substantial endurance swimming developed. Whether these potential performances are actually realized in the field remains to be determined, but they provide the potential to strongly influence dispersal.
\end{abstract}

KEY WORDS: Dispersal · Ontogeny $\cdot$ Swimming $\cdot$ Larvae $\cdot$ Critical speed $\cdot$ Endurance $\cdot$ Fish $\cdot$ Sparidae $\cdot$ Sciaenidae $\cdot$ Percichthyidae

Resale or republication not permitted without written consent of the publisher

\section{INTRODUCTION}

Most demersal, marine and estuarine teleost fishes have a pelagic larval phase, followed by more sedentary juvenile and adult stages. During this larval phase, which can last for days to months, larvae have the potential to passively travel great distances with currents and disperse over a wide area (Roberts 1997, Leis \& McCormick 2002). Previously, the available data suggested that the swimming abilities of larval fishes in the horizontal plane were very limited (reviewed by Miller et al. 1988), and were largely irrelevant to issues of dispersal.

In contrast, recent laboratory and in situ studies have shown that larvae of many fish species - but not all- are 'effective' swimmers (sensu Leis \& Stobutzki 1999), meaning they are able to swim faster than mean ambient current speeds, especially in later stages of development (Stobutzki \& Bellwood 1994, Leis \& CarsonEwart 1997, 2003, Fisher et al. 2000, Jenkins \& Welsford 2002, Trnski 2002). Further, larvae of many species are able to swim unexpectedly long distances, at least in the laboratory and in the later stages of development (Stobutzki \& Bellwood 1997, Stobutzki 1998, Dudley et al. 2000, Fisher et al. 2000, Fisher \& Bellwood 2001, 2002). These swimming capabilities bring into question the long-standing belief that fish larvae are passively distributed by currents (e.g. Williams et al. 1984, Roberts 1997) and show the 
importance of incorporating larval behaviour into models of dispersal (Armsworth 2000, Leis 2002).

Modelling of transport pathways from spawning site to settlement location is important for understanding larval dispersal and recruitment (Miller et al. 1988, Cowen et al. 2000, Leis 2002) as larval dispersal will largely determine the geographical extent of population units of marine demersal fishes. This in turn has implications for the management of fisheries and marine protected areas (e.g. Cowen et al. 2000, Leis 2002). Recent analyses suggest that sensory and swimming abilities of larvae are at least as important as fine-scale circulation when determining recruitment of fishes (Armsworth 2000, Armsworth et al. 2001, Sponaugle et al. 2002, Kingsford et al. 2002). For example, Wolanski \& Sarsenski (1997) showed that only when swimming and orientation by larvae were incorporated into a numerical dispersal model did the predicted distribution of reef-fish larvae match that actually observed.

Work to date on swimming capabilities of larvae of demersal fish species has concentrated on larvae nearing settlement (Leis \& McCormick 2002, Jenkins \& Welsford 2002, Trnski 2002, Leis \& Carson-Ewart 2003). Although this provides valuable information on the final portion of the pelagic larval phase, smaller, younger, less developed larvae are unlikely to have equivalent performance. Before we can adequately understand the influence that swimming ability of larvae has on dispersal and recruitment, we need to know at what stage during ontogeny 'effective' swimming develops. Fisher et al. (2000) approached this question by studying, throughout the post-hatching development phase, reared larvae of 3 tropical reef-fish species (Pomacentridae and Apogonidae), all of which hatch from non-pelagic eggs, unlike the majority of marine fishes. Ontogenetic increases in swimming abilities varied among species, and swimming abilities capable of influencing dispersal developed at an early age (Fisher et al. 2000). Fisher et al. (2000) also suggested that the ontogenetic trajectory of swimming abilities of larvae that hatch from pelagic eggs would differ from the species they studied.

We adopted an approach similar to that of Fisher et al. (2000), but examined the swimming ability of larvae of 4 species of warm temperate perciform food fishes that hatch from pelagic eggs: Argyrosomus japonicus (Temminck \& Schlegel) (mulloway, Sciaenidae), Pagrus auratus (Bloch \& Schneider) (snapper, Sparidae), Acanthopagrus australis (Owen) (yellowfin bream, Sparidae), and Macquaria novemaculeata (Steindachner) (Australian bass, Percichthyidae). The aims of this study were therefore: (1) to determine the ontogeny of critical speed and endurance swimming ability in the larvae of these species; (2) to compare these ontogenies among the species studied here, and to other perciform species for which suitable data are available; and (3) to provide information that will enable estimation of when during development, swimming abilities become sufficient to influence dispersal.

The third aim is entirely context dependent: because current speeds vary temporally and spatially, both vertically and horizontally, what constitutes effective swimming will vary. Clearly, effective swimmers can directly influence dispersal (Sponaugle et al. 2002). Slower-swimming individuals may also directly influence dispersal in coastal waters because non-tidal currents run primarily parallel to shore and depth contours, but larvae must move toward shore to find settlement habitat (Sponaugle et al. 2002). In the vertical plane, relatively weak swimming can indirectly influence dispersal where and when current velocity varies vertically (Sponaugle et al. 2002, Paris \& Cowen 2004). We provide information on ontogenetic changes in swimming abilities that will allow context-dependent application to particular environments and to dispersal models that incorporate larval behaviour.

\section{MATERIALS AND METHODS}

Swimming chamber. A multi-lane swimming chamber was used to measure critical speed and endurance swimming ability in larvae (Stobutzki \& Bellwood 1994). The chamber was made of clear perspex with 6 lane-ways, each $30 \mathrm{~mm}$ wide, $50 \mathrm{~mm}$ high and $180 \mathrm{~mm}$ long. Aside from the fine mesh $(0.5 \mathrm{~mm})$ ends, it was identical to that of Stobutzki \& Bellwood (1994, 1997). An area of the lid was shaded black to provide the larvae with a point of reference while swimming.

Even distribution of flow was achieved by a T-piece diffuser in the header portion of the chamber. Turbulence in the chamber was minimised by a $40 \mathrm{~mm}$ long section of flow straighteners just before the start of each lane-way. Water flow speed was controlled by adjusting a calibrated valve. Flow rates were calibrated by recording the time taken for water flowing over the chamber's outlet weir to fill a container of known volume, divided by the cross-sectional area of the chamber. The average of 5 calibrations was used as the flow speed for the valve angle. The system was calibrated each time the chamber was set up. Flow speeds ranged from 1 to $32 \mathrm{~cm} \mathrm{~s}^{-1}$.

This chamber design has negligible boundary layers (Stobutzki \& Bellwood 1997, Stobutzki 1998, Fisher et al. 2000). The water velocity in the $5 \mathrm{~mm}$ closest to the wall was not significantly different to that in the centre of the chamber (Stobutzki \& Bellwood 1997). In the present study, fish were not seen to take refuge along the sides or bottom of the chamber. 
Larvae. The following 4 species of commerciallyimportant temperate marine fishes were studied: Argyrosomus japonicus (Sciaenidae), Pagrus auratus (Sparidae), Acanthopagrus australis (Sparidae), and Macquaria novemaculeata (Percichthyidae) (Table 1). All larvae were obtained from aquaculture facilities providing rearing stock for commercial culture. Larvae of $A$. japonicus and $P$. auratus were reared at New South Wales Fisheries (NSWF), Port Stephens Re-search Centre, in $2000 \mathrm{l}$ aquaria at 22.6 to $24^{\circ} \mathrm{C}$, under a 14:10 h light:dark photoperiod. The larvae were fed rotifers Brachionus plicatilis from $4 \mathrm{~d}$ after hatching (dah) and brine shrimp Artemia nauplii from 15 dah (Fielder \& Bardsley 1999). Larvae of A. australis were reared at Searle Aquaculture (SA), northern NSW in $2500 \mathrm{l}$ aquaria at 21 to $23^{\circ} \mathrm{C}$, in a hothouse providing 70 to $80 \%$ ambient light. The larvae were fed rotifers and copepod nauplii from 3 to 4 dah and Artemia nauplii from 14 dah. Larvae of $M$. novemaculeata were reared at both NSWF and SA. At SA, larvae of $M$. novemaculeata were reared outdoors in $1500 \mathrm{l}$ aquaria at 19 to $21^{\circ} \mathrm{C}$, with 10 to $20 \%$ ambient light. The larvae were fed rotifers and copepod nauplii from 3 dah and Artemia nauplii from 12 dah. At NSWF, $M$. novemaculeata larvae were reared in $2000 \mathrm{l}$ intensive, clearwater, recirculation tanks (with biofiltration). From hatching until inflation of the swimbladder the water temperature was $18^{\circ} \mathrm{C}$, the photoperiod was 12:12 h light:dark, and larvae were fed rotifers. With swimbladder inflation, water temperature was changed to $20^{\circ} \mathrm{C}$, photoperiod to $18: 6 \mathrm{~h}$ light:dark, and food to Artemia. These rearing protocols had been developed to optimize growth and survival of each species.

Swimming methodology. Larvae were haphazardly removed from their rearing tank using a bucket or beaker. Water from the swimming chamber system

Table 1. Argyrosomus japonicus, Pagrus auratus, Acanthoppagrus australis, Macquaria novemaculeata. Numbers, sizes, ages, and stages of reared larvae used for measurements of critical speed and endurance. The values of $n$ exclude $P$. auratus larvae with uninflated swimbladders (see 'Results'); 'best performers' are in parentheses (see 'Materials and methods'). dah: days after hatch; Pre: preflexion; F: flexion; Post: postflexion

\begin{tabular}{|c|c|c|c|c|c|}
\hline & $\mathrm{n}$ & $\begin{array}{l}\text { Ages } \\
\text { (dah) }\end{array}$ & $\begin{array}{c}\text { Sizes } \\
(\mathrm{SL}, \mathrm{mm})\end{array}$ & Stages & Cohorts \\
\hline \multicolumn{6}{|l|}{ Critical speed } \\
\hline A. japonicus & $134(39)$ & $15-32$ & $4.2-11.5$ & Pre, F, Post & $1,2,3$ \\
\hline$P$. auratus & $56(17)$ & $11-30$ & $2.2-10.0$ & Pre, Post & 2,3 \\
\hline A. australis & $78(18)$ & $31-35$ & $4.9-10.7$ & F, Post & 1 \\
\hline M. novemaculeata & 41 (16) & $33-40$ & $5.0-10.4$ & F, Post & 1,2 \\
\hline \multicolumn{6}{|l|}{ Endurance } \\
\hline A. japonicus & $214(40)$ & $6-32$ & $3.5-13.3$ & Pre, F, Post & $1,2,3,4$ \\
\hline$P$. auratus & $29(13)$ & $11-28$ & $2.2-9.6$ & Pre, Post & $1,2,3$ \\
\hline M. novemaculeata & $29(13)$ & $14-41$ & $4.0-10.0$ & F, Post & $2,3,4$ \\
\hline
\end{tabular}

was gradually added to the container to allow the larvae to acclimatise to any differences in water quality.

Larvae were dipped from the container, using a glass vial to minimise handling stress, and 1 larva was placed in each chamber lane-way. Larvae were allowed 5 to $10 \mathrm{~min}$ to acclimatise to the chamber with the flow speed at $1 \mathrm{~cm} \mathrm{~s}^{-1}$. Any larva showing signs of stress during the acclimation period was removed from the experiment and replaced with another individual. Two swimming parameters were measured: critical speed $\left(U_{\text {crit }}\right)$, which measures swimming speed with incremental increases over successive 5 min periods; and endurance, which measures how long (time and distance) larvae can swim without food or rest. Water temperature in the swimming chamber ranged from 19 to $24^{\circ} \mathrm{C}$ depending on species and location.

For $U_{\text {crit }}$ tests, starting at $1.5 \mathrm{~cm} \mathrm{~s}^{-1}$, current speed was increased by approximately $2 \mathrm{~cm} \mathrm{~s}^{-1}$ every $5 \mathrm{~min}$ until the larvae were unable to swim against the current. The time at which each larva became fatigued was recorded. Critical speed ( $\left.U_{\text {crit }}\right)$ of larvae was calculated following Brett (1964):

$$
U_{\text {crit }}=U+\left(t / t_{\mathrm{i}} \times U_{\mathrm{i}}\right)
$$

where, $U=$ penultimate speed, $U_{\mathrm{i}}=$ speed increment (ca. $2 \mathrm{~cm} \mathrm{~s}^{-1}$, in the present study), $t=$ time swum in the final speed increment, and $t_{\mathrm{i}}=$ the time interval for each velocity increment (5 min).

For endurance tests, a constant flow speed was normally used. The speed selected was $10 \mathrm{~cm} \mathrm{~s}^{-1}$. This approximates the modal current speed when the East Australian Current is not impinging on the continental shelf in the Tasman Sea ca. $4 \mathrm{~km}$ off the coast near Sydney, Australia (ca. 34 ${ }^{\circ}$ ) (Rendell \& Pritchard 1997) where larvae of these species are known to occur (Neira et al 1998, Smith 2003, Trnski et al. 2005). However, young larvae (1 to $15 \mathrm{dah}$, preflexion and flexion-stages, 3.5 to $5 \mathrm{~mm}$ standard length, SL) were unable to swim at this speed and were consequently swum at a constant, slower speed in the range of 2 to $8 \mathrm{~cm} \mathrm{~s}^{-1}$, depending on species. This slower speed was selected on the basis of the larvae's ability to swim during the first minute of testing. This provided a non-zero mean estimate of endurance swimming ability for the smallest larvae, but in all cases, these small larvae had low endurance (the maximum 'small-larva' endurance was 40 to $133 \mathrm{~m}$, depending on species), and the reported results differ little from the zero endurance values that would have been obtained at $10 \mathrm{~cm} \mathrm{~s}^{-1}$. Data on 12 Macquaria novemaculeata 
larvae came from trials when speed was progressively increased so the end of the trial could be reached within time constraints. Speeds up to $20 \mathrm{~cm} \mathrm{~s}^{-1}$ were used. Fisher \& Bellwood (2002) have shown that larvae of some reef fishes can swim greater distances at slower speeds, so it is likely that endurance measures gathered on the 12 larvae where speed was increased are conservative relative to larvae swum at lower, constant speed. Larvae swam without food or rest until they became fatigued, which was defined as when a larva no longer was able to hold its position against the current, and drifted into the downstream mesh in its lane-way, and remained there. This took between $1 \mathrm{~min}$ and $5 \mathrm{~d}$. During daylight hours, larvae were constantly observed and the exact time fatigue occured was recorded. At night larvae were observed every $5 \mathrm{~h}$, and the time of fatigue was the midpoint between when the larva was last seen swimming and when it was found no longer swimming. Measurements were made outdoors under shade, with ambient light during the day, and illumination from a fluorescent light at night. The swimming duration was converted into distance swum $(\mathrm{km})$ using the flow speed. The larvae did not actually swim this distance relative to any fixed point, but they did relative to the moving water in which they swam. This is analogous to a non-passive fish swimming in the ocean in a moving water column (i.e. a current): the fish may not move relative to the bottom, but it does move relative to the water column. The values are therefore given as km swum. The number, age, stage and size of larvae used (Table 1) depended on availability of larvae from the aquaculture facilities, and the ability of younger larvae to swim in the experimental conditions. We used larvae of sizes expected to be pelagic in the field (Table 2).

Fatigued larvae from both experiments were removed from the chamber and fixed in Bouin's solution for $1 \mathrm{~h}$, then transferred into $70 \%$ ethanol. Preserved larvae were later examined under a dissection microscope to determine SL, state of flexion of the notochord, total body area in lateral projection, and propulsive area (Fisher et al. 2000). Areas were measured using Scion Image software. Propulsive area was the total lateral body area (including fins) minus the head and gut, and had an overall average of approximately $52 \%$ of the total area for Argyrosomus japonicus, $58 \%$ for Pagrus auratus, $67 \%$ for Acanthopagrus australis and $72 \%$ for Macquaria novemaculeata larvae (see 'Results' for more details).

Morphological development. All body sizes of larvae are given as SL unless stated otherwise. For each day that experiments were conducted, several larvae that had not been swum were fixed in alcohol. These specimens were later cleared and stained (Taylor \& Van Dyke 1985) so that cartilage and bone development could be assessed. Data from cleared and stained larvae were: body size, the number of cartilage and ossified vertebrae present, the stage of flexion of the notochord, and the number of fin rays present as cartilage and bone in the caudal and dorsal fins. Attainment of morphological landmarks in Figs. 1 to 4 was expressed as mean SL at attainment.

Data analysis. To determine the best predictor of performance, critical swimming speed and endurance values were regressed against age (dah), and the ontogenetic proxies of SL, propulsive area and total area, using linear, logarithmic, power and exponential models. The model with the greatest $\mathrm{R}^{2}$ was accepted as the best description. An ontogenetic index can be useful to standardize comparisons among species with different ontogenies (e.g. Fuiman et al. 1998). We did not use such an index primarily because the 4 species we studied were of similar morphology and attained morphological milestones at similar sizes. One species settled at a size several mm larger than the others, but this is an ecological, not a morphological, difference.

Depending on species, 1 to 4 cohorts of larvae were used (Table 1). Cohorts were compared by examination of scatterplots and regression lines of performance versus size. Cohorts were compared statistically using analysis of covariance (ANCOVA) with Tukey's test as a post-hoc test. The assumptions of homogeneity were tested using general linear models (GLM) for all ANCOVAs.

For each species, the best performers for each $1 \mathrm{~mm}$ size increment were examined separately. The best performers per $1 \mathrm{~mm}$ increment represent between 25 and $35 \%$ of the total number of individuals examined

Table 2. Argyrosomus japonicus, Pagrus auratus, Acanthopagrus australis, Macquaria novemaculeata. Size (SL mm) of reared larvae of 4 fish species at morphological and ecological landmarks. For settlement, (1) S. Fielder pers. comm., (2) Neira et al. (1998), (3) Trnski (2002) and (4) Trnski et al. (2005). Unreferenced values from the present study

\begin{tabular}{|c|c|c|c|c|c|}
\hline Species & $\begin{array}{l}\text { Notochord } \\
\text { flexion }\end{array}$ & $\begin{array}{l}\text { Vertebral column } \\
\text { ossification }\end{array}$ & $\begin{array}{l}\text { Caudal fin } \\
\text { completion }\end{array}$ & $\begin{array}{l}\text { Dorsal fin } \\
\text { completion }\end{array}$ & Settlement \\
\hline A. japonicus & $6.2-6.4$ & $8.4-8.6$ & $9.0-9.3$ & $9.3-9.5$ & $12-13(1)$ \\
\hline$P$. auratus & $5.1-5.2$ & $7.0-7.1$ & $8.0-8.5$ & $8.5-9.0$ & $9-12(2,3)$ \\
\hline A. australis & $5.0-5.2$ & $5.6-5.8$ & $6.4-6.5$ & $6.9-7.1$ & 8-11 (3) \\
\hline M. novemaculeata & $5.7-5.9$ & $6.6-6.8$ & $9.1-9.3$ & $10.1-10.3$ & $9-10(4)$ \\
\hline
\end{tabular}


for each species, the variation being due to the number of individuals available and our desire to have at least 2 'best performers' per $1 \mathrm{~mm}$ increment to ensure reasonable replication. For each $1 \mathrm{~mm}$ increment, this corresponded to the best 5 performers in both critical speed and endurance in Argyrosomus japonicus, the best 3 performers in critical speed in Acanthopagrus australis, Pagrus auratus and Macquaria novemaculeata, and the best 2 performers in endurance for the latter two species (Table 1). When there were $\leq 3$ individuals per $1 \mathrm{~mm}$ increment, only 1 best performer was selected for that increment.

Reynold's number ( $R e)$ is a measure of the ratio of forces that arise from viscous and inertial effects as a fish swims through water (Webb \& Weihs 1986). $\operatorname{Re}=(L \times$ $U$ ) / v, where $L=$ body length (m), $U=$ swimming speed $\left(\mathrm{m} \mathrm{s}^{-1}\right)$, and $v=$ kinematic viscosity of seawater at $20^{\circ} \mathrm{C}$ $\left(1.03 \times 10^{-6} \mathrm{~m}^{2} \mathrm{~s}^{-1}\right)$. Re was calculated for all larvae for which critical swimming speed was measured to determine if the larvae were swimming at speeds where either viscous (conventionally considered to be $\mathrm{Re}<200$ ) or inertial $(\operatorname{Re}>200)$ forces predominate.

\section{RESULTS}

In all cases, variation among individuals in performance at any ontogenetic stage was large, and swimming performance increased with development, regardless of the ontogenetic proxy used. Overall, size proved a better measure of larval development in relation to swimming performance than did age. For development of $U_{\text {crit }}$ and endurance size, rather than age, provided a far better fit in 4 cases (with $\mathrm{R}^{2}$ values 0.20 to 0.48 higher), whereas in 3 cases, size and age provided equivalent fits. For critical speed and endurance, propulsive area (PA) and SL provided similar fits, with maximum $\mathrm{R}^{2}$ difference of $<0.09$. Therefore, all results are reported in relation to body size ( $\mathrm{SL}$, in $\mathrm{mm}$ ). Overall, growth in SL ranged from 0.13 to $0.50 \mathrm{~mm} \mathrm{~d}^{-1}$, depending on species, which is similar to growth rates in the ocean for larvae of many fish species. At any age, the range in SL of each species was as much as $7.7 \mathrm{~mm}$, although the mean size range at any age was 2 to $3 \mathrm{~mm}$, depending on species.

\section{Variation among cohorts}

Some differences in performance were found among cohorts in Argyrosomus japonicus and Pagrus auratus, but none were found for Macquaria novemaculeata, and only 1 cohort of Acanthopagrus australis was used. For A. japonicus, differences in ontogeny of performance among cohorts were apparently largely the result of differences between cohorts in size structure or in variance in performance, and we retained data from all cohorts. In cohort 2 of $P$. auratus, about half the larvae had swimbladders that failed to inflate, which is abnormal, and did not occur in other cohorts. Larvae with uninflated swimbladders swam at one third the speed and half the distance, on average, of larvae with inflated swimbladders. We therefore removed cohort 2 $P$. auratus larvae with uninflated swimbladders from further analysis, but retained all other larvae.

\section{Swimming performance}

In all 4 species, ontogenetic increase in critical speed (Figs. 1 to 4) was best described by either a linear model (Argyrosomus japonicus, Acanthopagrus australis), or a 'flat' curvi-linear model (Pagrus auratus, Macquaria novemaculeata) (Table 3). The fastest individual for each species swam at 16.6 to $27.3 \mathrm{~cm} \mathrm{~s}^{-1}$ (A. japonicus and $P$. auratus, respectively) at sizes ranging from 7.2 to $10.4 \mathrm{~mm}$ SL (not necessarily the largest individual tested). The best performing larvae had critical speed versus size relationships that were similar to those of average larvae (Table 3 ), except that in $M$. novemaculeata, critical speed of the best performers did not increase significantly with size over the size range we studied. Critical speeds at any given size were 1 to $5 \mathrm{~cm} \mathrm{~s}^{-1}$ faster for the best performers than for average larvae. The difference between best and average performers was least for $M$. novemaculeata (1.2 to $2.4 \mathrm{~cm} \mathrm{~s}^{-1}$ ) and greatest for A. australis (3 to $5 \mathrm{~cm} \mathrm{~s}^{-1}$ ).

In all 3 species, the ontogenetic increase in swimming endurance (Figs. 1, 2 \& 4) was best described by exponential or power models that were strongly concave (Table 3) with a marked increase in endurance after 7 to $9 \mathrm{~mm} \mathrm{SL}$, depending on species. The longest-swimming individual of each species swam 9.9 to $22.4 \mathrm{~km}$ (Pagrus auratus and Argyrosomus japonicus, respectively) at sizes of 9.2 to $10.0 \mathrm{~mm}$ SL. It should be noted, however, that for $P$. auratus, we had no endurance data for specimens of 5.0 to $6.8 \mathrm{~mm}$ (Fig. 2), so the shape of the increase in endurance with growth during the flexion and early postflexion stage is unclear. Endurance was about $4 \mathrm{~km}$ by the end of this hiatus. Further, for Macquaria novemaculeata endurance measures are likely to be minimum values because about half of the data come from larvae that were not tested at a constant speed (see 'Materials and methods'). The best performing larvae had endurance versus size relationships that were similar to those of average larvae (Table 3), but in $M$. novemaculeata and A. japonicus endurance increased at a greater rate for best performing larvae than for average larvae. In $P$. auratus and A. japonicus, best performing larger 


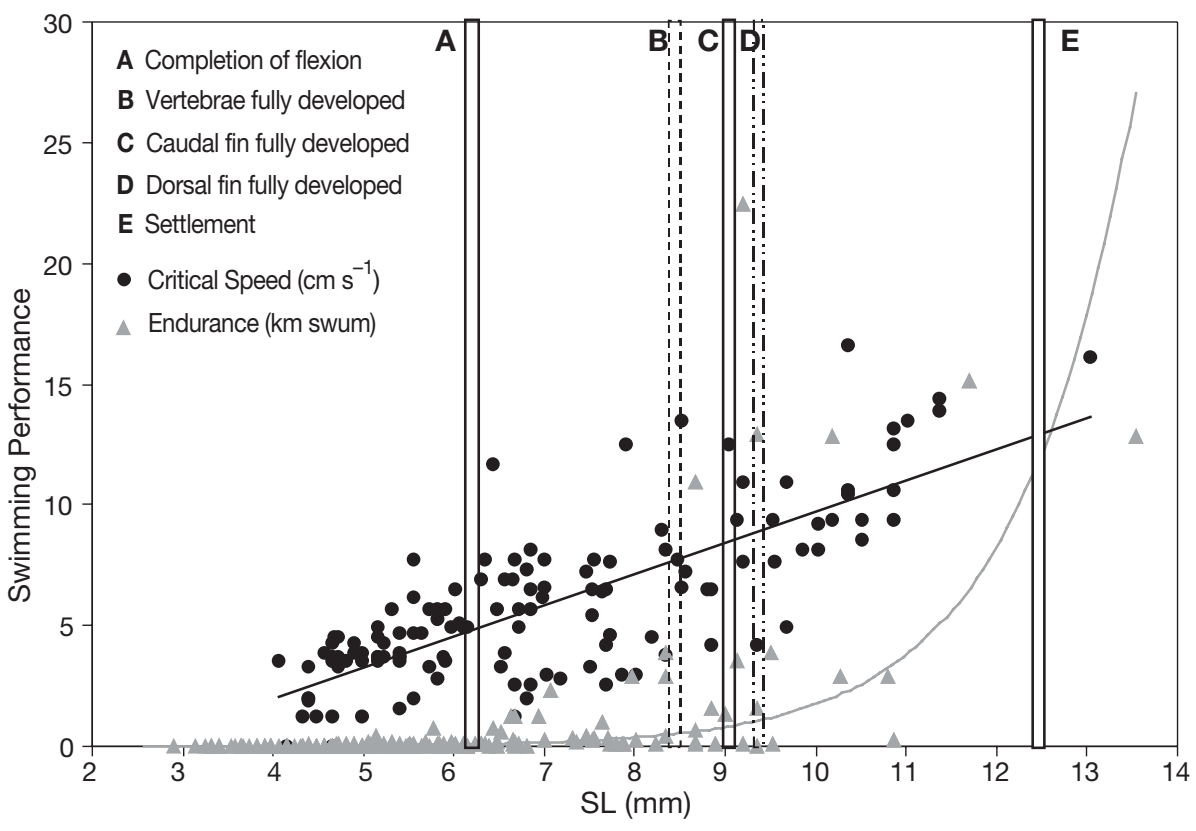

Fig. 1. Argyrosomus japonicus. Ontogeny of swimming performance in larvae. Bars represent attainment of morphological landmarks and settlement. Critical speed, $\mathrm{n}=134$; endurance, $\mathrm{n}=214$. Equations for the best-fit lines are in Table 3

larvae (ca. 9 to $10 \mathrm{~mm}$ SL) swam about 1 and $10 \mathrm{~km}$ further, respectively, than average larvae. In $M$. novemaculeata, best performers were able to swim about twice as far as average larvae. Endurance was not measured in Acanthopagrus australis.

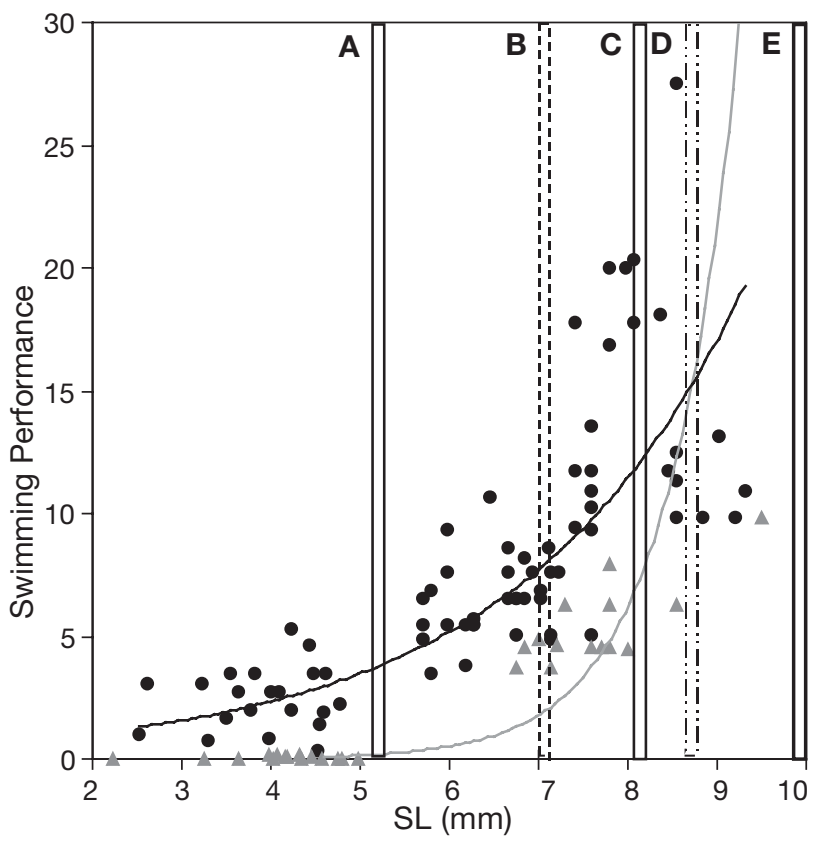

Fig. 2. Pagrus auratus. Ontogeny of swimming performance in larvae. Bars represent attainment of morphological landmarks and settlement. Critical speed, $\mathrm{n}=57$; endurance $\mathrm{n}=29$. Equations for the best-fit lines are in Table 3. See Fig. 1 for explanation of letters and symbols
The ontogeny of swimming performance can be related to morphological milestones derived from cleared and stained specimens (Table 2). Critical speed increased linearly with growth in Argyrosomus japonicus and Acanthopagrus australis, and was not obvi-ously related to any morphological development other than growth. In Pagrus auratus larvae, critical speed increased at a somewhat greater rate per unit growth following flexion. In the 2 species for which we had data on preflexion larvae, postflexion larvae had mean critical speeds 3 to 4 times the mean speeds of preflexion larvae. In contrast, endurance was very low (4 to $133 \mathrm{~m}$ ) in all species prior to flexion, and improved at an increasing rate once flexion was complete. In A. japonicus, although mean endurance values remained low for some time following flexion (not reaching $1 \mathrm{~km}$ until after $8 \mathrm{~mm}$ SL, and trending strongly upward from that point), the first endurance values in excess of $1 \mathrm{~km}$ appeared within $1 \mathrm{~mm}$ SL after the completion of flexion (Fig. 1, Table 2). In P. auratus, the exact timing of the increase was unclear due to a hia-

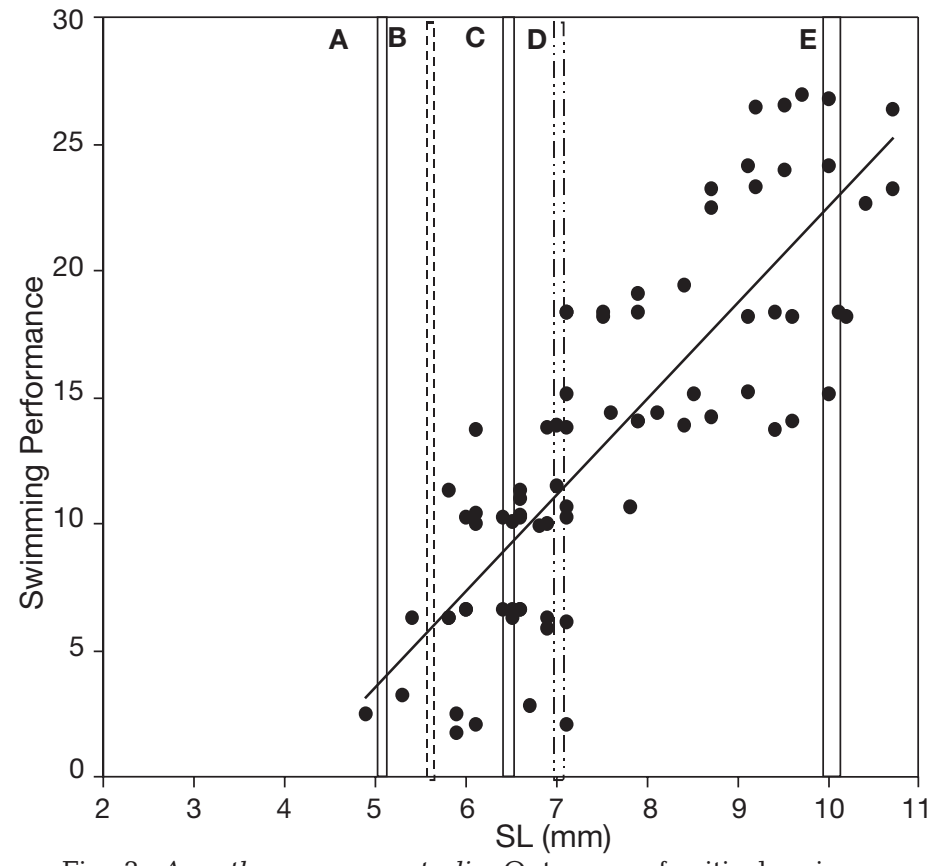

Fig. 3. Acanthopagrus australis. Ontogeny of critical swimming speed in larvae. Bars represent attainment of morphological landmarks and settlement. $n=78$. Equation of the best fit line is in Table 3. See Fig. 1 for explanations of letters and symbols 


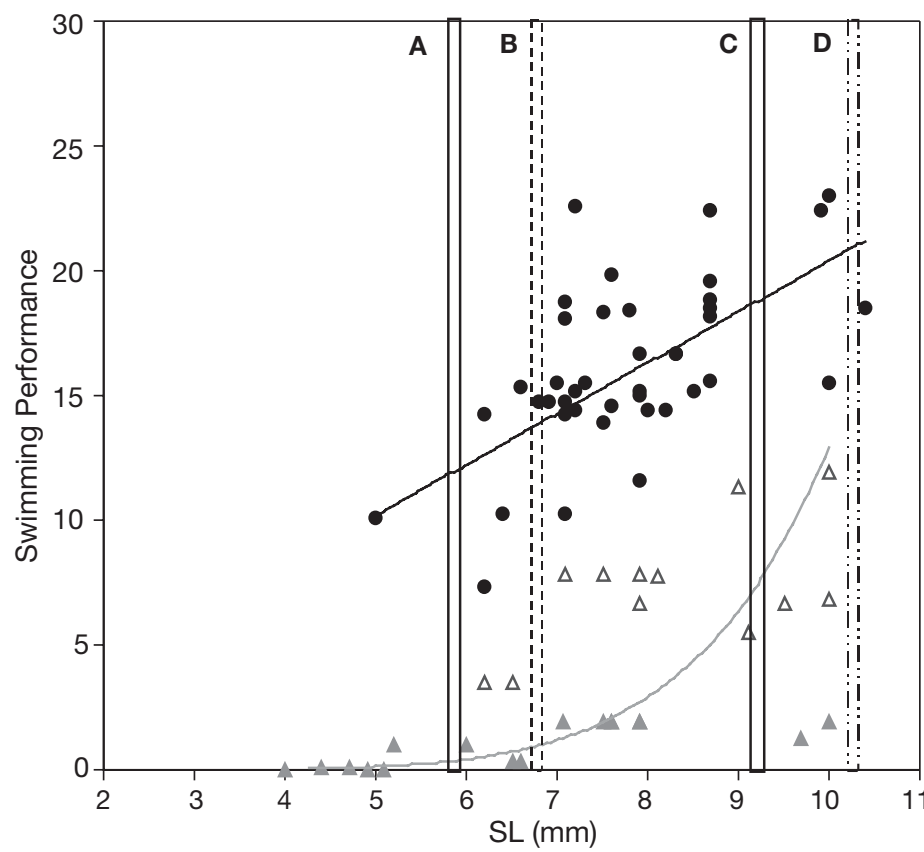

Fig. 4. Macquaria novemaculeata. Ontogeny of swimming performance in larvae. Bars represent attainment of morphological landmarks and settlement. Critical speed, $\mathrm{n}=41$; endurance, $n=29$. $\Delta$ : individuals for which speed was increased during endurance measurements, possibly resulting in underestimates of endurance. Equations for the best-fit lines are in Table 3. See Fig. 1 for explanations of letters and symbols

tus in the endurance data during the flexion and early post-flexion stage, but it was close to the completion of flexion (Fig. 2, Table 2). In Macquaria novemaculeata, the increase in endurance clearly took place shortly after flexion was complete (Fig. 4, Table 2).

\section{Comparison among species}

The lines fitted to the data in Figs. 1 to 4 (Table 3) are the models that best described the relation between performance and size for the full data sets in each case, but over particular size ranges (primarily with larger larvae, where $\mathrm{n}$ may be relatively low, especially for endurance because the larvae swam for so long), the overall model may not describe performance well. For comparisons among species, we plotted mean performance over $1 \mathrm{~mm}$ size intervals without regard to any descriptive model of the performance versus size relationship (Figs. 5 \& 6).

Over the size range (5 to $10 \mathrm{~mm} \mathrm{SL}$ ) for which we had data for all 4 species, Macquaria novemaculeata was initially the fastest swimmer, but Acanthopagrus australis had equivalent speeds by about $8 \mathrm{~mm}$, and the 2 species were thereafter similar (Fig. 5). Pagrus auratus was intermediate in speed (the apparent drop in speed in the 9 to $10 \mathrm{~mm}$ category is perhaps an artefact of having data for only 3 individuals), with speeds about 4 to $5 \mathrm{~cm} \mathrm{~s}^{-1}$ slower than $M$. novemaculeata at all sizes and A. australis after $8 \mathrm{~mm}$ SL. Throughout, Argyrosomus japonicus was the slowest swimmer by 3 to $7 \mathrm{~cm} \mathrm{~s}^{-1}$ relative to $P$. auratus, and by about $12 \mathrm{~cm} \mathrm{~s}^{-1}$ compared to $M$. novemaculeata and A. australis. At about $4 \mathrm{~mm}$, the 2 sparid species had critical speeds similar to $A$. japonicus, but by $9 \mathrm{~mm}$, their speeds were 2 to 3 times that of $A$. japonicus, and similar to M. novemaculeata. Presumably, M. novemaculeata larvae smaller than we studied had a very rapid increase in swimming speed per unit growth: the 2 flexion-stage $M$. novemaculeata larvae had average $U_{\text {crit }}$ about $10 \mathrm{~cm} \mathrm{~s}^{-1}$, about twice that of flexion-stage larvae from the other 3 species.

In all 4 species, we found a roughly linear increase in critical speed with growth over the common size range, with an increase of 1.2 to $2.6 \mathrm{~cm} \mathrm{~s}^{-1}$ per mm growth (Fig. 5). Argyrosomus japonicus had the slowest rate of increase, whereas Acanthopagrus australis had the fastest. At settlement size, A. japonicus, which settle at a larger size than the other 3 species (Table 2), had a critical speed of about $15 \mathrm{~cm} \mathrm{~s}^{-1}$, which was similar to that of settlement-stage Pagrus auratus, but about $5 \mathrm{~cm}$ $\mathrm{s}^{-1}$ less than A. australis and Macquaria novemaculeata (Fig. 5). The best performing larvae provided a generally similar picture of relative performance among these 4 species.

Until flexion was complete, endurance was low in all 3 tested species, and seldom exceeded $100 \mathrm{~m}$. The

Table 3. Argyrosomus japonicus, Pagrus auratus, Acanthopagrus australis, Macquaria novemaculeata. Relationship between size (SL mm) and swimming performance for all larvae, and for the best performers. $\mathrm{p}<0.05$ for all but the best-performing $M$. novemaculeata under critical speed. Curves for all larvae are shown in Figs. 1 to 4, where values of $\mathrm{n}$ are provided

\begin{tabular}{|c|c|c|c|c|}
\hline \multirow[t]{2}{*}{ Species } & \multicolumn{2}{|c|}{ - Critical speed $\left(\mathrm{cm} \mathrm{s}^{-1}\right)$} & \multicolumn{2}{|c|}{ - Endurance $(\mathrm{km})$} \\
\hline & All & Best & All & Best \\
\hline A. japonicus & $1.30 \mathrm{SL}-3.20, \mathrm{R}^{2}=0.60$ & $1.35 \mathrm{SL}-0.74, \mathrm{R}^{2}=0.74$ & $9 \times 10^{-5} \mathrm{e}^{1.01 \mathrm{SL}}, \mathrm{R}^{2}=0.50$ & $0.0028 \mathrm{e}^{0.764 \mathrm{SL}}, \mathrm{R}^{2}=0.81$ \\
\hline P. auratus & $0.47 \mathrm{e}^{0.41 \mathrm{SL}}, \mathrm{R}^{2}=0.70$ & $0.97 \mathrm{e}^{0.35 \mathrm{SL}}, \mathrm{R}^{2}=0.90$ & $0.0003 \mathrm{e}^{1.25 \mathrm{SL}}, \mathrm{R}^{2}=0.83$ & $0.0043 \mathrm{e}^{0.79 S \mathrm{~L}}, \mathrm{R}^{2}=0.65$ \\
\hline A. australis & $3.81 \mathrm{SL}-15.55, \mathrm{R}^{2}=0.68$ & $3.98 \mathrm{SL}-12.80, \mathrm{R}^{2}=0.90$ & & \\
\hline M. novemaculetaa & $2.03 \mathrm{SL}^{1.01}, \mathrm{R}^{2}=0.39$ & $6.14 \mathrm{SL}^{0.52}, \mathrm{R}^{2}=0.28(\mathrm{NS})$ & $3 \times 10^{-6} \mathrm{SL}^{6.68}, \mathrm{R}^{2}=0.69$ & $6 \times 10^{-7} \mathrm{SL}^{6.99}, \mathrm{R}^{2}=0.72$ \\
\hline
\end{tabular}




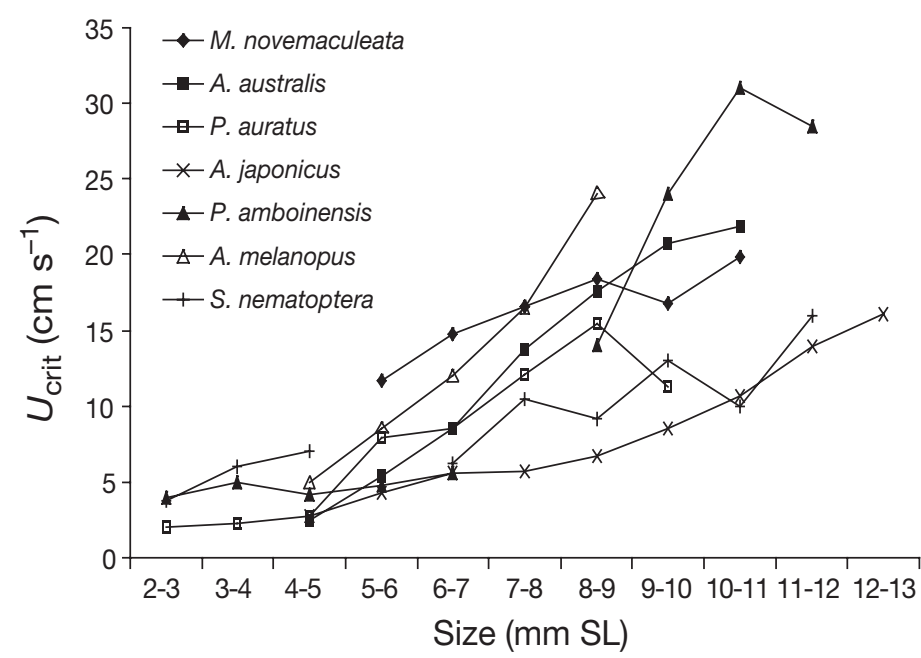

Fig. 5. Ontogeny of swimming speed $\left(U_{\text {crit }}\right)$ based on mean performance in each $1 \mathrm{~mm}$ size increment of growth for the larvae of the 4 species in this study and 3 species (Amphiprion melanopus, Pomacentrus amboinensis and Sphaeramia nematoptera) taken from Fig. 5A of Fisher et al. (2000), and converted to SL from total length. Note gaps in data for $P$. amboinensis and $S$. nematoptera for 7 to $8 \mathrm{~mm}$ and 5 to $6 \mathrm{~mm}$ size increments, respectively. Species with the same shape of symbol are from the same family

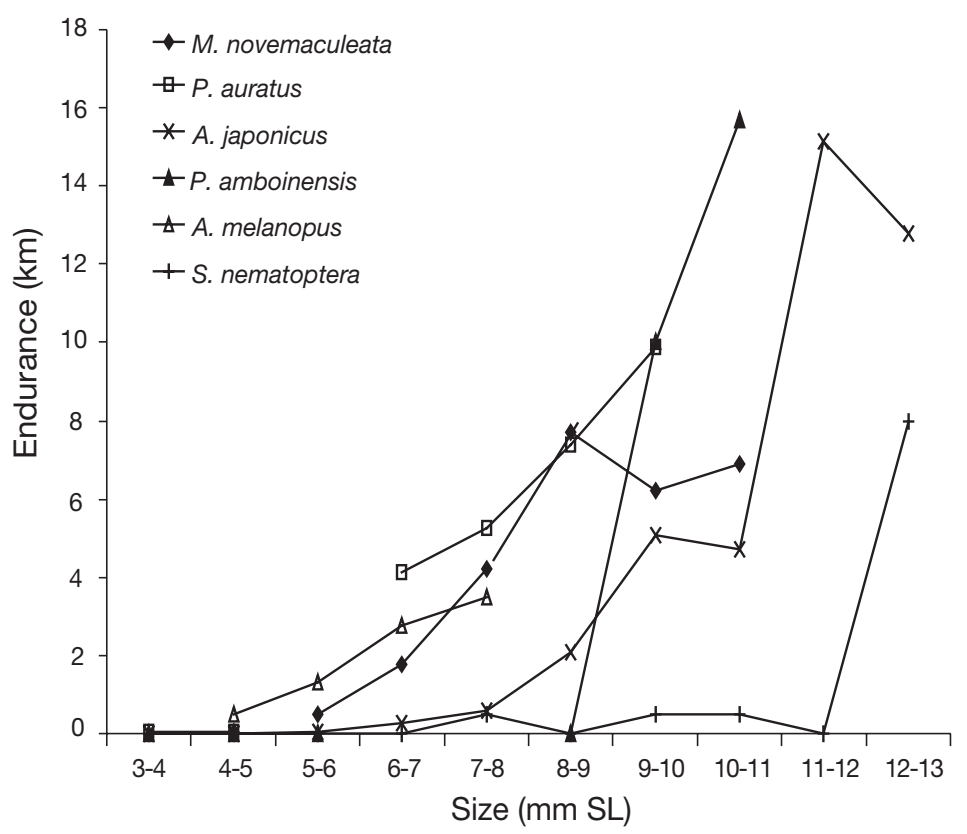

Fig. 6. Ontogeny of endurance swimming based on mean performance in each $1 \mathrm{~mm}$ size increment of growth for the larvae of the 3 species in this study and 3 species taken from Fig. 6B of Fisher et al. (2000) and converted to SL from total length. Not shown is a mean value of $55 \mathrm{~km}$ for the 12 to $13 \mathrm{~mm}$ size interval of Pomacentrus amboinensis. Note gaps in data for $P$. amboinensis for 6 to 8 and 11 to $12 \mathrm{~mm}$, and Pagrus auratus for 5 to $6 \mathrm{~mm}$ size increments. Species with the same shape of symbol are from the same family first species to have notable endurance swimming capabilities were Macquaria novemaculeata and Pagrus auratus at about 6 to $7 \mathrm{~mm}$. In these 2 species, mean endurance values increased from about $250 \mathrm{~m}$ at 4 to $5 \mathrm{~mm}$ to about 3 to $4 \mathrm{~km}$ at 6 to $7 \mathrm{~mm}$ (Figs. 2, $4 \& 6)$. At 6 to $7 \mathrm{~mm}, A$. japonicus endurance averaged about $250 \mathrm{~m}$, although some individuals swam much further (Figs. $1 \& 6$ ). By 9 to $10 \mathrm{~mm}$, the range in mean endurance in these 3 species was 5 to $10 \mathrm{~km}$ (Figs. 1, 2, 4 \& 6), with maximum values of about $12 \mathrm{~km}$. Again, A. japonicus had the lowest values. However, because $A$. japonicus settles at a larger size than the other 2 species (Table 2), at settlement, A. japonicus, had the greatest endurance (14 to $15 \mathrm{~km}$ ) of the 3 (Fig. 6). The best performers had a generally similar relative increase in endurance with growth among species, with the exception that A. japonicus did relatively better amongst the best performing larvae than it did amongst average larvae (Table 3). Recall that endurance values for M. novemaculeata may be somewhat underestimated (Fig. 4), so this species may, in fact, have the best endurance performance of the 3 species studied

When the critical speed data are scaled to body length (BL s ${ }^{-1}$ based on SL), a slightly different picture emerges. The 2 sparids had a marked increase in scaled speed $\left(\mathrm{BL} \mathrm{s} \mathrm{s}^{-1}\right)$ with growth, increasing at about 2.5 to $2.8 \mathrm{BL} \mathrm{s}^{-1}$ per $\mathrm{mm}$, with maximum speeds of about $20 \mathrm{BL} \mathrm{s}^{-1}$ (Table 4). Scaled speed also increased with growth in Argyrosomus japonicus, but the rate was much less at about $0.8 \mathrm{BL} \mathrm{s}^{-1}$ per $\mathrm{mm}$ and was about $12 \mathrm{BL} \mathrm{s}^{-1}$ in the largest larvae. For A. japonicus, size explained a much smaller proportion of the variation in scaled speed than it did in the sparids (Table 4). Macquaria novemaculeata, in contrast, did not increase in scaled speed across the range of sizes we tested. In fact, there was a weak decrease in scaled speed with growth (Table 4), with mean values across the size range of about $20 \mathrm{BL} \mathrm{s}^{-1}$.

Based on SL, Acanthopagrus australis reached all morphological milestones first, followed by Pagrus auratus, followed by equal last Argyrosomus japonicus and Macquaria novemaculeata (Table 2). This did not

Table 4. Argyrosomus japonicus, Pagrus auratus, Acanthopagrus australis, Macquaria novemaculeata. Relationship between size (SL: $\mathrm{mm}$ ) and critical speed scaled as body lengths $\left(\mathrm{BL} \mathrm{s}^{-1}\right)$ in reared larvae of 4 temperate marine fishes

\begin{tabular}{|lccc|}
\hline Species & $U_{\text {crit }}\left(\mathrm{BL} \mathrm{s}^{-1}\right)$ & $\mathrm{R}^{2}$ & $\mathrm{p}$ \\
\hline A. japonicus & $0.83 \mathrm{SL}+1.61$ & 0.24 & $<0.01$ \\
P. auratus & $2.46 \mathrm{SL}-5.21$ & 0.46 & $<0.01$ \\
A. australis & $2.83 \mathrm{SL}-4.90$ & 0.39 & $<0.01$ \\
M. novemaculeata & $-0.72 \mathrm{SL}+26.02$ & 0.04 & $>0.05$ \\
\hline
\end{tabular}


Table 5. Argyrosomus japonicus, Pagrus auratus, Acanthopagrus australis, Macquaria novemaculeata. Best fit of propulsive area (PA: $\mathrm{mm}^{2}$ ) to size (SL: $\mathrm{mm}$ ) for reared larvae of the 4 species considered here. Other than $A$. japonicus, all species have very similar values, indicating similar morphologies

\begin{tabular}{|lcc|}
\hline Species & PA vs. SL relationship & $\mathrm{R}^{2}$ \\
\hline A. japonicus & $\mathrm{PA}=0.069 \mathrm{SL}^{2.33}$ & 0.89 \\
$P$. auratus & $\mathrm{PA}=0.036 \mathrm{SL}^{2.78}$ & 0.96 \\
A. australis & $\mathrm{PA}=0.030 \mathrm{SL}^{2.80}$ & 0.95 \\
M. novemaculeata & $\mathrm{PA}=0.038 \mathrm{SL}^{2.75}$ & 0.93 \\
\hline
\end{tabular}

match development of swimming ability. Other than notochord flexion, and concomitant formation of the caudal fin, none of the morphological milestones we examined seemed to greatly influence swimming performance.

Propulsive area as a possible predictor of performance serves to differentiate Argyrosomus japonicus from the other 3 species, as it had smaller addition of propulsive area per unit growth (Table 5). This correlates with the slower increase in swimming performance per unit growth in $A$. japonicus. The other 3 species are very similar in morphology (Table 5), but Pagrus auratus and Macquaria novemaculeata had about 15 to $20 \%$ more propulsive area at any size than did Acanthopagrus australis. This does not clearly correlate with development of swimming abilities among the 3 species.

The transition from viscous to inertial swimming is conventionally considered to take place at Reynold's Number (Re) of about 200 (Blaxter 1986). Based on $U_{\text {crit, }}$ the 4 species considered here attained $\operatorname{Re}>200$ in $50 \%$ of individuals between 3 and $4 \mathrm{~mm}$. By 4.5 to $5 \mathrm{~mm}, 100 \%$ of individuals had attained $\mathrm{Re}>200$. Clearly, by conventional criteria, postflexion larvae were in an inertial environment at their critical speeds, whereas most preflexion larvae were in a viscous environment.

\section{DISCUSSION}

The 4 species studied here are perciform fishes that hatch from small $(<1 \mathrm{~mm})$ pelagic eggs and reach moderate to large adult sizes, with adult habitats that range from freshwater/estuarine (Macquaria novemaculeata), to shallow coastal/estuarine (Acanthopagrus australis) to coastal at shallow to moderate depths (Argyrosomus japonicus, Pagrus auratus). The families represented are Sparidae, Sciaenidae and Percichthyidae. All 4 species have a life history that includes an estuarine habitat: $M$. novemaculeata spends nearly all of its life cycle in estuaries and freshwater (Trnski et al. in press), as do the related northern hemisphere moro- nids, whereas the other 3 spend at least their immediate post-settlement juvenile stage in estuaries. The morphological development of these 4 species is similar, with relatively direct development, few specializations to pelagic larval life, and settlement at 8 to $12 \mathrm{~mm}$ about 1 mo after spawning (Neira et al. 1998, Trnski et al. 2005). At settlement all are distinctly 'larval' in appearance (relatively small, transparent, without scales, and with small body mass).

Not surprisingly, all species became more competent swimmers with growth, but the rate at which this happened differed among species. The percichthyid, Macquaria novemaculeata, was the best swimmer of the 4 species until about $7 \mathrm{~mm}$ SL. This species did not, however, demonstrate a great increase in $U_{\text {crit }}$ across the ontogenetic range we examined, presumably meaning that $M$. novemaculeata preflexion stages (which we did not study) are good swimmers with critical speeds considerably greater than those of preflexion larvae of the other 3 species, as was the case for flexion-stage larvae. The 2 sparids had similar ontogeny of swimming performance, and were second overall to the percichthyid until one of them equalled it at about $8 \mathrm{~mm}$. The sciaenid was the weakest swimmer, and had the slowest increase in performance with growth of the 4 species. It also had the smallest propulsive area as a percentage of body area due to its relatively large head. Other than this, propulsive area was not a superior predictor of swimming performance, or even loosely correlated with relative performance among the 4 species we studied, a outcome in contrast to some other studies (e.g. Fisher et al. 2000).

Of the 4 species, 3 had an increase in scaled critical speed $\left(\mathrm{BL} \mathrm{s}^{-1}\right)$ with growth, but the rate of increase differed among species. The sparids increased at a greater rate than the sciaenid. The scaled speeds at settlement of about $20 \mathrm{BL} \mathrm{s} \mathrm{s}^{-1}$ in the sparids and the percichthyid, and $12 \mathrm{BL} \mathrm{s}^{-1}$ for the sciaenid are within the range of scaled critical speeds reported for coralreef fish larvae at settlement (Fisher et al. 2000, Bellwood \& Fisher 2001, Leis \& Fisher in press), an indication that the putative temperate versus tropical dichotomy in performance of fish larvae is probably overstated (Dudley et al. 2000, Trnski 2002). Other than Fisher et al. (2000), most previous reports have based scaled speed of larvae not on critical speed, but on unforced lab-based measures of larval swimming speed, which is probably why they were only 1 to $5 \mathrm{BL} \mathrm{s}^{-1}$ (Miller et al. 1988), much lower than the critical speeds reported here.

We found some differences among cohorts in swimming performance, but have retained data from all cohorts on the basis that this variation likely encompasses that found in nature. Further, there is no basis for selec- 
ting any given cohort as most representative. In contrast, we excluded data from larvae with uninflated swimbladders. Swimbladder inflation offers a larva potential energy savings via achievement of neutral buoyancy, and this has obvious benefits in endurance swimming, and probably attainment of speed. Given that normal development includes inflation of the swimbladder relatively early in ontogeny, deletion of data from larvae with uninflated swimbladders is appropriate.

Age was a poor predictor of swimming performance, not unexpectedly, because 'a given ontogenetic state is usually reached at a uniform size for a species, regardless of how long it takes to achieve it' (Fuiman \& Higgs 1997, Fuiman et al. 1998). The poor explanatory power of age is exacerbated further in the present study as a result of the wide range of sizes of larvae at any age, and for some species, the relatively narrow range of ages we had to work with. Presumably, the more slowly-growing reared larvae would have been culled in the wild, but can survive in the predator-free, benign aquaculture environment (Kingsford \& Atkinson 1994). In the ocean, the average fish larva does not survive given the very high mortality rates between spawning and settlement (Houde 1989, Cushing 1990). If it is assumed that the small percentage of larvae that survive to settlement in the wild are the best performers, whether in terms of growth (e.g. Vigliola \& Meekan 2002) or swimming abilities, this promotes the desirability of using the data from the best performers, rather than average performers, in both recruitment and dispersal models. The best performers swam 2 to $5 \mathrm{~cm} \mathrm{~s}^{-1}$ faster and up to twice as far as average performers, and will, therefore, have considerably more control over their trajectories than the average larva. Models that contrast the dispersal of average versus best performers could provide valuable insight.

Our results broadly conform with those of Fisher et al. (2000) who studied 3 tropical reef species of the families Apogonidae and Pomacentridae that hatched from non pelagic eggs. Both studies found that critical speed increased relatively constantly with development (Fig. 5), in a roughly linear manner. In contrast, in most species, endurance increased markedly at some point following notochord flexion and concomitant formation of the caudal fin (Fig. 6). The size at which the marked increase in endurance took place varied from very soon after flexion (e.g. Pagrus auratus) to about twice the size at which flexion was complete (e.g. Sphaeramia nematoptera). Among the 6 species for which there are data, only Amphiprion melanopus did not have a marked post-flexion increase in endurance abilities (Fig. 6). Rather, endurance in this species increased gradually in a linear manner.

Comparison of the available information on ontogenetic increase in critical speed in larvae of marine per- ciform fishes reveals little evidence of a temperate-tropical dichotomy (Fig. 5, data from the present study and from Fisher et al. 2000). The 2 species with the slowest increase in performance are a tropical apogonid and a temperate sciaenid. 2 temperate species (a sparid and a percichthyid) and a tropical pomacentrid had the most rapid ontogenetic increase in critical speed, whereas a second tropical pomacentrid and a temperate sparid had intermediate rates of increase. The second tropical pomacentrid (Pomacentrus amboinensis) did, however, go on to have the greatest speed, but only after about $9 \mathrm{~mm}$, when its morphology began to diverge from that of the of the sparids, the percicithyid and the first tropical pomacentrid and at sizes greater than the settlement size of the other taxa. With the possible exception of $P$. amboinensis (for which data are not available for the critical size of 7 to $8 \mathrm{~mm} \mathrm{SL}$ ), all increases in critical speed with size were roughly linear.

We found no difference in endurance between temperate and tropical species either in development or in maximum values (Fig. 6). Examination of the data in Fig. 6 for 3 species each from tropical and temperate environments shows no tropical-temperate differences in the size at which significant values of endurance first develop, the rate at which endurance improves, or the maximum endurance. For example, among these 6 species, a tropical pomacentrid had the highest endurance, but another tropical pomacentrid had the lowest endurance. It must be noted, however, that the 3 species studied by Fisher et al. (2000) are not among the strongest swimming tropical species at settlement (Leis \& Fisher in press), and the species we studied, although temperate in an Australian context, live at temperatures of ca 15 to $24^{\circ} \mathrm{C}$. Therefore, comparisons that include species from cooler waters may reveal more differences between tropical and temperate species than the available data currently show.

Compared to the temperate species studied here, the pelagic stages of many tropical reef-fish species are frequently less 'larval' in appearance (relatively large, often pigmented, scaled, and robust with substantial muscle mass) at settlement (Leis \& Carson-Ewart 2004). It may be the case that average performance of tropical species at settlement is greater than that of temperate species (Leis \& McCormick 2002), but there is considerable overlap in performance (see Figs. 5 \& 6), and comparisons are made difficult by differences in methodology among studies. These apparent tropical/temperate differences are probably due more to phylogeny than latitude, as within a family, larval development and morphology at settlement differ little between temperate and tropical species. This can readily be seen in the Sparidae and Sciaenidae (e.g. Neira et al. 1998, Leis \& Carson-Ewart 2004) which have both temperate and tropical species. Per- 
cichthyids are essentially temperate in distribution so temperate-tropical comparisons cannot be made. Larval morphology and size of larvae at settlement are important influences on swimming ability (Fisher et al. in press). Related species tend to have similar swimming performance (Leis \& Carson-Ewart 1997, Fisher \& Wilson 2004), and of course, related species also tend to have similar morphology and size at settlement (Leis \& CarsonEwart 2004).

Higher temperature decreases the viscosity of water and increases muscle efficiency, both of which would be predicted to result in better swimming performance at the higher temperatures that prevail in the tropics (Hunt von Herbing 2002). So, temperature per se may be an influence in temperate-tropical comparisons, with better performance for any species expected at higher temperatures. In the present study, the species with the poorest performance (Argyrosomus japonicus) was tested at temperatures up to $5^{\circ} \mathrm{C}$ higher than the species with the best performance (Macquaria novemaculeata), so there was no indication that the relative ranking of performance among species was affected by differences in test temperature.

There was no clear dichotomy in performance between species that spawn pelagic eggs, and those that spawn non-pelagic eggs when comparisons are based on size of the larvae. The slow sciaenid hatches from a pelagic egg, and the equally slow apogonid hatches from orally-brooded eggs. Among the faster species, the 2 pomacentrids hatch from demersal eggs, and the sparids and percichthyid hatch from pelagic eggs. The frequently-proposed better swimming performance of larvae from non-pelagic eggs (Leis 1991) may apply when age, in terms of days after hatch, is the ontogenetic proxy, but if size is used instead, any supposed advantage disappears, at least in the available species. Because the average pomacentrid or apogonid hatches at a more developed state from larger demersal eggs (Leis \& Carson-Ewart 2004), they would presumably have less time between hatching and the start of effective swimming than does the average species that hatches from pelagic eggs. Adults of the 3 species studied by Fisher et al. (2000) are small species of little commercial interest, whereas the 4 species studied here are all food fishes of considerable sport or commercial importance. The fact that the ontogeny of swimming was similar in the 2 groups is a further indication that at the larval scale, small fishes like pomacentrids are little different from large, commercially important species (Leis $\&$ McCormick 2002)

The ontogeny of 'routine swimming' of 4 perciform fishes - a carangid (Sakakura \& Tsukamoto 1999), a sciaenid (Fuiman et al. 1999), a sparid (Fukuhara 1985) and a scombrid (Hunter \& Kimmrell 1980) was similar to the ontogeny of critical speed in the species we studied. Routine speed - the mean rate of travel during undisturbed activity (Fuiman et al. 1999) - is a measure of unforced swimming in the laboratory, often in small containers, and is not directly comparable to critical speed. For carangids, sciaenids and sparids routine speeds in the above studies were about 10 to $15 \%$ of the critical speeds measured here (perhaps because larvae of at least some species swim slower in small containers than in large ones, Theilacker \& Dorsey 1980), whereas scombrids were faster, and had performance similar to Pagrus auratus. One can, however, compare the ontogenetic increase in routine speed to that of critical speed. In these 4 species, the ontogenetic increase in routine speed with growth was best described by a straight line or a 'flat' power curve (Hunter \& Kimbrell's [1980] published curve, and our analysis of data provided by Fukuhara 1985, Sakakura \& Tsukamoto 1999 and Fuiman et al. 1999). This is similar to our results. In both critical and routine speeds sparid larvae had a greater ontogenetic increase in performance than did sciaenid larvae.

When applying the results on swimming abilities of fish larvae to dispersal models it is important to recognize the limitations of laboratory measurements such as those presented here. Critical speed is a laboratory measure of forced performance over minutes, and is unlikely to represent cruising speed of larvae in the wild. Actual swimming speeds in situ are certain to be less than critical speeds (Leis \& Carson-Ewart 1997, Leis \& Stobutzki 1999), perhaps only half (Leis \& Fisher in press). Fisher \& Bellwood (2003) estimate that in 3 species 'undisturbed swimming speed' (similar to routine speed) in the laboratory was about half of critical speed. Endurance swimming ability, in contrast, is a conservative value because it is normally measured in the laboratory with unfed larvae, and larvae allowed to feed-as they certainly do in the field-can swim much further (Fisher \& Bellwood 2001, Leis \& Clark 2005).

Whether larvae swim in a viscous or an inertial environment has implications for their ability to swim for extended periods, as it is much more costly energetically to swim in a viscous environment than an inertial one (Webb \& Weihs 1986). After notochord flexion at about $5 \mathrm{~mm} \mathrm{SL}$, the larvae we studied were clearly capable of swimming in an inertial environment, and it is at this point in development that endurance swimming abilities started to become substantial. Indeed, endurance began to increase at an increasing rate from about $5 \mathrm{~mm}$ SL, when notochord flexion was complete. This strong increase in endurance may well be at least partially a result of more efficient swimming at higher Reynolds numbers as the larvae grow and swim faster. 
Use of reared larvae may not provide realistic results if the performance of reared larvae in the laboratory is worse that that of wild larvae in situ, but we found no indication of this. It is commonly asserted that swimming performance of reared larvae will be inferior to that of wild larvae (e.g. Blaxter 1975), although there are few direct comparisons, and the relative performance of reared and wild larvae may vary among developmental stages, or not differ at all (Smith \& Fuiman 2004). Wild larvae of the species studied here are difficult to obtain without damage, so we were unable to measure their swimming performance in the laboratory swimming chamber. There are, however, in situ swimming-speed observations of wild settlementstage larvae of Pagrus auratus (mean $10.9 \mathrm{~cm} \mathrm{~s}^{-1}$, SE 1.0, maximum $13.5 \mathrm{~cm} \mathrm{~s}^{-1}$ ), and Acanthopagrus australis (mean $7.1 \mathrm{~cm} \mathrm{~s}^{-1}, \mathrm{SE} 0.3, \max 13 \mathrm{~cm} \mathrm{~s}^{-1}$ ) (Trnski 2002). The mean (and SE) critical speeds of similarsized reared larvae of these 2 species were 15.9 (2.5), and $23.2(0.9) \mathrm{cm} \mathrm{s}^{-1}$, respectively. Although in situ speeds and critical speeds cannot be compared directly (e.g. Leis \& Stobutzki 1999), there was certainly no indication that the reared larvae were performing poorly relative to the wild ones.

In all cases, we found strong variation in swimming performance at any size, but larvae were able to swim at mean critical speeds of about $5 \mathrm{~cm} \mathrm{~s}^{-1}$ at about the time of notochord flexion, and of 10 to $20 \mathrm{~cm} \mathrm{~s}^{-1}$ by settlement. Prior to notochord flexion, swimming endurance was limited, meaning that the speeds quoted above can be maintained for only limited periods of time, and are likely to be most influential in vertical movements (e.g. Paris \& Cowen 2004), or perhaps in small-scale movements in the vicinity of sharp gradients, such as estuarine fronts (Sponaugle et al. 2002). By the time of settlement, greater swimming speeds can be applied for longer periods, with mean endurances on the order of $10 \mathrm{~km}$ or more over several days. At settlement, therefore, and for a substantial portion of the postflexion larval period, all 4 species have the ability to exert considerable influence over their dispersal trajectories through horizontal swimming. The best performing individuals can do considerably better, with speeds 2 to $5 \mathrm{~cm} \mathrm{~s}^{-1}$ better than average, and endurances up to twice that of average performance.

In these 4 temperate species, until flexion is complete both speed and endurance are limited. After caudal fin formation, swimming performance improves markedly at a species-specific rate, and by the time of settlement, the larvae of these 4 species have the ability to swim over substantial distances at speeds that probably exceed the average current speeds in their coastal environment. It is important to acknowledge, that as the development of the caudal fin is size-dependent, size and developmental state are inexorably confounded, and increase in size, per se, rather than developmental events such as caudal-fin formation, may be the important factor in increased swimming performance.

It is difficult to apply ages to the ontogenetic events documented here, as growth rates derived from culture situations are unlikely to be relevant to field conditions and estimates of growth rates of larvae in the ocean are available for only 1 of the 4 species studied here. In wild Pagrus auratus, hatching from a pelagic egg takes place in about $24 \mathrm{~h}$ (S. Fielder pers. comm.), notochord flexion at 5 to $6 \mathrm{~mm}$ is reached about 16 to 18 dah and settlement size of $10 \mathrm{~mm}$ in about 30 dah (Kingsford \& Atkinson 1994). Presumably, development rates of the other 3 species are similar, and settlement would be expected to occur about 4 wk after hatching (Benoit et al. 2000). Therefore, swimming by the larvae should be an important factor in dispersal for about half of the pelagic larval period.

Whether these potential performances are actually realized in the field remains to be determined, and actual measurements of performance in the field are needed to 'calibrate' these laboratory measurements (Leis \& Fisher in press). The lab-based measures can, however, be applied to what is known of the distribution of the larvae of these 4 species to estimate the potential for swimming to influence distributions. Larvae of 3 of the species considered here occur from very close to shore to as far as 12 to $16 \mathrm{~km}$ offshore in the Sydney region (ca $34^{\circ} \mathrm{S}$ on the SE Australian coast, Smith 2003), whereas Macquaria novemaculeata apparently has a more restricted, nearshore distribution (Trnski et al. 2005). If they swam at average critical speed, these species would become effective swimmers in this region - where modal current speeds are less than $10 \mathrm{~cm} \mathrm{~s}^{-1}$ when the East Australian Current is not impinging on the continental shelf (Rendell \& Pritchard 1997) - at 5 to $10 \mathrm{~mm} \mathrm{SL}$, depending on the species. At settlement size, larvae of these species swimming at average critical speed would take 16 to $26 \mathrm{~h}$ to reach shore from 12 to $16 \mathrm{~km}$ offshore. Average settlement-size larvae would be capable of swimming at least the $12 \mathrm{~km}$ distance at $10 \mathrm{~cm} \mathrm{~s}^{-1}$ without food or rest, and probably 3 times that distance if they fed (Fisher \& Bellwood 2001, Leis \& Clark 2005). The best performers could do much better. Therefore, it is not unreasonable to expect that settlement stage larvae could reach the coast actively by swimming alone from most of the continental-shelf locations at which they have been reported to occur, and departures from passive drift with the current are possible much earlier.

The among-species differences in ontogeny of swimming performance that we document here may be related to the life histories of the species involved, or to their phylogenies. The larvae of Macquaria novemacu- 
leata are better swimmers - in terms of both speed and endurance - at a smaller size than are the other 3 species. This percichthyid has a more estuarine earlylife history than the other species (Trnski et al. 2005), so if staying in or near to estuaries during the larval phase is important, there might be selection for early development of swimming abilities. The 2 sparids have similar development of performance, with good speed and endurance by mid-way through the post-flexion larval period. They have similar life histories, whereby larvae over the continental shelf (Smith 2003) must find estuarine nurseries for settlement (Trnski 2002), and in the case of Acanthopagrus australis, an intermediate surf zone habitat is utilized (J.M. Leis et al. unpubl.). These might best be achieved by rapid development of swimming abilities part way through the pelagic larval period. The sciaenid, Argyrosomus japonicus, also undertakes its early pelagic larval phase over the continental shelf, but older, postflexion larvae are only rarely taken in conventional plankton samples (Smith 2003): they may descend to near the bottom, as do larvae of some other sciaenid species (Barnett et al. 1984). If so, then the lower current speeds typically found in epibenthic boundary layers may not demand swimming abilities as well-developed as in other species with larvae in the upper water column. Alternatively, these different patterns of development of swimming abilities may have more to do with phylogeny than ecology, with different patterns in each family. Only additional studies on other species and areas will shed light on this.

Acknowledgements. We are indebted to S. Fielder of New South Wales Fisheries and G. Searle of Searle Aquaculture for providing the larvae used in this study. We are also grateful for the assistance provided by L. Cheviot, M. Lockett, M. Brown and G. Howarth in obtaining these data. Thanks to R. Fisher and 3 anonymous reviewers for constructive comments on this paper. This work was supported by the NSW Government via the late Australian Museum Centre for Biodiversity and Conservation Research and by an ARC Discovery Grant (DP0345876) to JML.

\section{LITERATURE CITED}

Armsworth PR, James MK, Bode L (2001) When to press on, wait or turn back: dispersal strategies for reef fish larvae. Am Nat 157:434-450

Armsworth PR (2000) Modelling the swimming response of late stage larval reef fish to different stimuli. Mar Ecol Prog Ser 195:231-247

Barnett AM, Jahn AE, Sertic PD, Watson W (1984) Distribution of ichthyoplankton off San Onofre, California, and methods for sampling very shallow coastal waters. US Fish Bull 82:97-111

Bellwood DR, Fisher R (2001) Relative swimming speeds in reef fish larvae. Mar Ecol Prog Ser 211:299-303

Benoit HP, Pepin P, Brown JA (2000) Patterns of metamorphic age and length in marine fishes, from individuals to taxa. Can J Fish Aquat Sci 57:856-869

Blaxter JHS (1975) Reared and wild fish - how do they compare? Proc 10th Eur Symp Mar Biol 1:11-26

Blaxter JHS (1986) Development of sense organs and behavior of teleost larvae with special reference to feeding and predator avoidance. Trans Am Fish Soc 115:98-114

Brett JR (1964) The respiratory metabolism and swimming performance of young sockeye salmon. J Fish Res Board Can 21:1183-1226

Cowen RK, Lwiza KMM, Sponaugle S, Paris CB, Olson DB (2000) Connectivity of marine populations: open or closed? Science 287:857-859

Cushing DH (1990) Plankton production and year class strength in fish populations: an update of the match/mismatch hypothesis. Adv Mar Biol 26:249-293

Dudley B, Tolimieri N, Montgomery J (2000) Swimming ability of the larvae of some reef fishes from New Zealand waters. Mar Freshw Res 51:783-787

Fielder DS, Bardsley W (1999) A preliminary study on the effects of salinity on growth and survival of mulloway Argyrosomus japonicus larvae and juveniles. J World Aquacult Soc 30:380-387

Fisher R, Bellwood DR (2001) Effects of feeding on the sustained swimming abilities of late-stage larval Amphiprion melanopus. Coral Reefs 20:151-154

Fisher R, Bellwood DR (2002) The influence of swimming speed on sustained swimming performance of late-stage reef fish larvae. Mar Biol 140:801-807

Fisher R, Bellwood DR (2003) Undisturbed swimming behaviour and nocturnal activity of coral reef fish larvae. Mar Ecol Prog Ser 263:177-188

Fisher R, Wilson SK (2004) Maximum sustainable swimming speeds of late-stage larvae of nine species of reef fishes. J Exp Mar Biol Ecol 312:171-186

Fisher R, Bellwood DR, Job SD (2000) Development of swimming abilities in reef fish larvae. Mar Ecol Prog Ser 202: 163-173

Fisher R, Leis JM, Clark D, Wilson SK (in press) Critical swimming speeds of late-stage coral reef fish larvae: variation within species, among species and between locations. Mar Biol

Fuiman LA, Higgs DM (1997) Ontogeny, growth and the recruitment process. In: Chambers RC, Trippel EA (eds) Early life history and recruitment in fish populations. Chapman \& Hall, London, p 225-249

Fuiman LA, Poling KR, Higgs DM (1998) Quantifying developmental progress for comparative studies of larval fishes. Copeia 1998:602-611

Fuiman LA, Smith ME, Malley VN (1999) Ontogeny of routine swimming speed and startle responses in red drum, with a comparison of responses to acoustic and visual stimuli. J Fish Biol 55(Suppl A):215-226

Fukuhara O (1985) Functional morphology and behavior of early life stages of red sea bream. Bull Japan Soc Sci Fish 51:731-743

Houde ED (1989) Subtleties and episodes in the early life of fishes. J Fish Biol 35(Suppl A):29-38

Hunter JR, Kimbrell CA (1980) Early life history of Pacific mackerel, Scomber japonicus. US Fish Bull 78:89-101

Hunt von Herbing I (2002) Effects of temperature on larval fish swimming performance: the importance of physics to physiology. J Fish Biol 61:865-876

Jenkins GP, Welsford DC (2002) The swimming abilities of recently settled post-larvae of Sillaginodes punctata. J Fish Biol 60:1043-1050

Kingsford MJ, Atkinson MH (1994) Increments in otoliths and 
scales: how they relate to the age and early development of reared and wild larval and juvenile Pagrus auratus (Sparidae). Aust J Mar Freshw Res 45:1007-1021

Kingsford MJ, Leis JM, Shanks A, Lindeman K, Morgan S, Pineda J (2002) Sensory environments, larval abilities and local self-recruitment. Bull Mar Sci 70:309-340

Leis JM (1991) The pelagic phase of coral reef fishes: larval biology of coral reef fishes. In: Sale PF (ed) The ecology fishes on coral reefs. Academic Press, San Diego, CA, p 183-230

Leis JM (2002) Pacific coral-reef fishes: the implications of behaviour and ecology of larvae for biodiversity and conservation, and a reassessment of the open population paradigm. Env Biol Fish 65:199-208

Leis JM, Carson-Ewart BM (1997) Swimming speeds of the late larvae of some coral reef fishes. Mar Ecol Prog Ser 159:165-174

Leis JM, Carson-Ewart BM (2003) Orientation of pelagic larvae of coral-reef fishes in the ocean. Mar Ecol Prog Ser 252:239-253

Leis JM, Carson-Ewart BM (eds) (2004) The larvae of IndoPacific coastal fishes, 2nd edn. Brill, Leiden

Leis JM, Clark DL (2005) Feeding greatly enhances endurance swimming of settlement-stage reef-fish larvae (Pomacentridae). Ichthyol Res 52:in press

Leis JM, Fisher R (in press) Swimming speed of settlementstage reef-fish larvae measured in the laboratory and in the field: a comparison of critical speed and in situ speed. Proc $10^{\text {th }}$ Int Coral Reef Symp, Okinawa

Leis JM, McCormick MI (2002) The biology, behaviour and ecology of the pelagic, larval stage of coral-reef fishes. In: Sale PF (ed) Coral reef fishes: New insights into their ecology. Academic Press, San Diego, CA, p 171-199

Leis JM, Stobutzki IC (1999) Swimming performance of late pelagic larvae of coral-reef fishes: in situ and laboratorybased measurements. In: Seret B, Sire J-Y (eds) Proc 5th Indo-Pacific Fish Conference, Noumea, 1997. Societe Francaise d'Ichtyologie \& Institut de Recherche pour le Developpment, Paris, p 575-583

Miller TJ, Crowder LB, Rice JA, Marschall EA (1988) Larval size and recruitment mechanisms in fishes: toward a conceptual framework. Can J Fish Aquat Sci 45:1657-1670

Neira FJ, Miskiewicz AG, Trnski T (eds) (1998) Larvae of temperate Australian fishes, laboratory guide for larval fish identification, 1st edn. University of Western Australia Press, Nedlands

Paris CB, Cowen RK (2004) Direct evidence of a biophysical retention mechanism for coral reef fish larvae. Limnol Oceanogr 49:1964-1979

Rendell PS, Pritchard TR (1997) Physiochemical conditions in coastal waters off Sydney, central NSW, Australia. Mar Poll Bull 33:07-12

Editorial responsibility: Howard Browman (Associate Editorin-Chief), Storebø, Norway
Roberts CM (1997) Connectivity and management of Caribbean coral reefs. Science 278:1454-1456

Sakakura Y, Tsukamoto, K (1999) Ontogeny of aggressive behaviour in schools of yellowtail, Seriola quinqueradiata Environ Biol Fish 56:231-242

Smith KA (2003) Larval distributions of some commercially valuable fish species over the Sydney continental shelf. Proc Linn Soc NSW 124:1-11

Smith ME, Fuiman LA (2004) Behavioural performance of wild-caught and laboratory-reared red drum Sciaenops ocellatus (Linneaus) larvae. J Exp Mar Biol Ecol 302: $17-33$

Sponaugle S, Cowen RK, Shanks A, Morgan SG and 7 others (2002) Predicting self-recruitment in marine populations: biophysical correlates. Bull Mar Sci 70:341-376

Stobutzki IC (1998) Interspecific variation in sustained swimming ability of late pelagic stage reef fish from two families (Pomacentridae and Chaetodontidae). Coral Reefs 17: $111-119$

Stobutzki IC, Bellwood DR (1994) An analysis of the sustained swimming abilities of pre- and post-settlement coral reef fishes. J Exp Mar Biol Ecol 175:275-286

Stobutzki IC, Bellwood DR (1997) Sustained swimming abilities of the late pelagic stages of coral reef fishes. Mar Ecol Prog Ser 149:35-41

Taylor WC, Van Dyke GC (1985) Revised procedures for staining and clearing small fishes and other vertebrates for bone and cartilage study. Cybium 9:107-119

Theilacker G, Dorsey K (1980) Larval fish diversity, a summary of laboratory and field research. UNESCO Intergov Oceanogr Comm Workshop Rep 28:105-142

Trnski T (2002) Behaviour of settlement-stage larvae of fishes with an estuarine juvenile phase: in situ observations in a warm-temperate estuary. Mar Ecol Prog Ser 242:205-214

Trnski T, Hay AC, Fielder DS (2005) Larval development of estuary perch (Macquaria colonrum) and Australian bass (M. novemaculeata) (Perciformes: Percichthyidae), with comments on their life history. US Fish Bull 103:183-194

Vigliola L, Meekan MG (2002) Size at hatching and planktonic growth determine post-settlement survivorship of a coral reef fish. Oecologia 131:89-93

Webb PW, Weihs D (1986) Functional locomotor morphology of early life history stages of fishes. Trans Am Fish Soc 115: $115-127$

Williams DMcB, Wolanski E, Andrews JC (1984) Transport mechanisms and the potential movement of planktonic larvae in the central region of the Great Barrier Reef. Coral Reefs 3:229-236

Wolanski E, Sarenski J (1997) Larvae dispersion in coral reefs and mangroves. Am Sci 85:236-243

Submitted: September 2, 2004; Accepted: November 30, 2004 Proofs received from author(s): March 17, 2005 